\title{
Real Estate Investment in Bangladesh: A Pre Liminary Study
}

\author{
Naheem Mahtab (Corresponding author) \\ School Of Business, Independent University, Bangladesh \\ Plot 16, Block B, Aftabuddin Ahmed Road, Bashundhara, Dhaka-1229, Bangladesh \\ E-mail: Naheem@Iub.Edu.Bd \\ Maqbool Kader Quraishi \\ School Of Business, Independent University,Bangladesh \\ Plot 16, Block B, Aftabuddin Ahmed Road, Bashundhara, Dhaka-1229, Bangladesh \\ E-mail: Quraishimk@Gmail.Com
}

\author{
Received: Sep. 8, 2014 Accepted: Oct. 14, $2014 \quad$ Published: December 1, 2014 \\ doi:10.5296/ajfa.v6i2.6286 URL: http://dx.doi.org/10.5296/ajfa.v6i2.6286
}

\begin{abstract}
Now a day's real estate investment through bank is a common phenomenon. Every single person or every house development company is used to take loans from banks or other financial institutions to complete their construction. Without bank loans it not possible to complete their construction on time. Income level is a very impressive influencing factor of real estate investment in our country. People don't want to spend whole amount construction cost from their own pocket that's why they are becoming dependent on loans of banks or other financial institution. Financing cost includes the interest payment of loans. Sometimes people are facing problem to repay the loans when any other political or natural instability stop their construction they the client of the bank are come to the defaulters list. There is a big issue in current real estate market that is low transparency of loans of financial institutions. When any financial institution provides loans to any house building company then they sometimes not disclose some terms related to loans then after some month or year the loan taking clients get some problems which is not good for the sector in Bangladesh.
\end{abstract}

Keywords: Real Estate Investment, Financing Cost, Political Risk, Transparency, Defaults 


\section{Introduction}

Real estate investing involves the purchase, ownership, management, rental and/or sale of real estate for profit. Real Estate has traditionally outperformed the Wall Street equity market. A Street by street knowledge of the market makes it perfect for small savvy investors. Large institutions lag behind trends. Improvement of realty property as part of a real estate investment strategy is generally considered to be a sub-specialty of real estate investing called real estate development. Real estate is an asset form with limited liquidity relative to other investments, it is also capital intensive (although capital may be gained through mortgage leverage) and is highly cash flow dependent. If these factors are not well understood and managed by the investor, real estate becomes a risky investment. The primary cause of investment failure for real estate is that the investor goes into negative cash flow for a period of time that is not sustainable, often forcing them to resell the property at a loss or go into insolvency. A similar practice known as flipping is another reason for failure as the nature of the investment is often associated with short term profit with less effort.

Once an investment property has been located, and preliminary due diligence (investigation and verification of the condition and status of the property) completed, the investor will have to negotiate a sale price and sale terms with the seller, then execute a contract for sale. Most investors employ real estate agents and real estate attorneys to assist with the acquisition process, as it can be quite complex and improperly executed transactions can be very costly. During the acquisition of a property, an investor will typically make a formal offer to buy including payment of "earnest money" to the seller at the start of negotiation to reserve the investor's rights to complete the transaction if price and terms can be satisfactorily negotiated. This earnest money may or may not be refundable, and is considered to be a signal of the seriousness of the investor's intent to purchase. The terms of the offer will also usually include a number of contingencies which allow the investor time to complete due diligence, inspect the property and obtain financing among other requirements prior to final purchase. Within the contingency period, the investor usually has the right to rescind the offer with no penalty and obtain a refund of earnest money deposits. Once contingencies have expired, rescinding the offer will usually require forfeiture of the earnest money deposits and may involve other penalties as well.

\section{Statement of Problem}

The problem statement of this research is--To investigate customers income level how extent related to the loans and why they are talking loans, their financial cost how cover with this loan facilities viewpoint on acquisition of real estate investment through bank loans.

\section{Purpose of the study}

The purpose of this study is to know about the consumers' income level, financing cost, property pricing and transparency of real estate market how effects the real estate investment through bank loans or any other financial organization. Customer's loan taking tendency from banks to make real estate financing can easily identify by this research. Acquisition of real estate investment through bank loan research is the process by which we can easily 
identify the house building organizations financial position and willingness towards bank loans. Real estate investment through bank loans is an effective tool for experience higher revenues on this sector.

- $\quad$ Focusing on income level and its correlation with real estate acquisition through bank loans and discussing the expertise of buying behaviour to know customers real estate investment intension.

- Verifying consumers 'dependency on loan products available for real estate acquisition and cost of loan recommendation before making the final purchase decision.

- Evaluating buying process which includes studying the need of transparency of information in the real estate market, cost of loan and evaluation of alternatives and acquisition behaviour of customers.

- Analysing the necessity of determining property prices and its influence on consumer decision making.

- Determining income level and the association of income with loan costs while using loans for real estate investment.

- Examine whether the customer belief on the available transparency of information in the real estate market is significant in relation to the loan cost of the loan used in the acquisition process of real estate in Bangladesh.

\section{Literature Review}

Income Level: The term social capital is often traced back to the work of the sociologist Bourdieu (1977), but it gained popularity with the seminal work of Coleman (1990) and Putnam (1993). Recently, Guiso et al. (2008) define social capital as "good" culture-i.e., a set of beliefs and values that facilitate cooperation among the members. The authors show that social capital can be measured by both direct indicators (such as generalized trust) and indirect indicators (such as blood donations).

There is a large consensus that heterogeneity is one important factor reducing the formation of social capital. Usually, community heterogeneity refers to income inequality but also ethnicity, and racial heterogeneity. In the present literature review, we concentrate our attention on economic inequality. Several mechanisms could explain the association between economic inequality and social capital.

First, individuals might be adverse to heterogeneity. In other words, they prefer having contacts with individuals that are similar to themselves, i.e. that belong to the same socioeconomic group. In heterogeneous societies contacts between dissimilar individuals will be at a lower rate than in more homogeneous societies. Repeated interactions being conducive of social capital and trust, heterogeneous societies are thus characterized by fewer contacts and, in consequence, by lower levels of cooperation and trust (see the seminal work by Colman, 1990, and Alesina et al, 2002 for instance). This aversion to heterogeneity can be driven by the fact that individuals from different socioeconomic groups are less likely to 
share common values and norms which makes it more difficult for them to predict the attitudes of others. This creates an environment not favorable to the development of social capital (Knack and Keefer, 1997).

Second, when resources are not evenly distributed, poor individuals might perceive that they are living in an unfair society where the rich tend to exploit the poor. This will lead individuals at the bottom end of the income distribution to develop distrust against richer individuals (Rothstein and Uslaner, 2004). Uslaner and Brown (2005) argue that when income inequality is high, individuals from different socioeconomic groups will have the sensation that they are not sharing the same fate, and this will hamper trust.

Third, inequality should relate to the level of optimism. Higher level of inequality is likely to reduce the level of optimism for the future and thereby trust (Uslaner and Brown, 2005, Rothstein and Uslaner, 2005). Most of the scholars interested in the relationship between social capital and income inequality have relied on trust as a proxy for social capital. The type of question used to assess the level of trust is "In general, do you think that most people can be trusted?" Fewer studies focus on different dimensions of social capital such as group membership, volunteering (Alesina and LaFerrara, 2000, Costas and Kahn, 2003, and Uslaner and Brown, 2005), informal social capital such as entertaining with friends and relatives (Lancee and Van de Werfhorst, 2011).

Transparency in real estate market: According to Jones Lang LaSalle (2006), transparent market in real estate context is a market fairly free from corruption and it has readily available information and operates in a fair and consistent manner. It has been argued that more transparent real estate markets attract greater levels of foreign investors as they become more comfortable and better informed (Jones Lang LaSalle, 2008). This argument is supported by previous studies (Jones Lang LaSalle, 2004, 2009; Dhar and Goetzmann, 2006). Jones Lang LaSalle (2008) noted that uncertainty respecting FREI laws could weaken investor confidence, caused confusion, negatively affected transparency and as a result decrease FDI into property sectors. In their comprehensive summary, Sirmans and Worzala (2003) concluded that international real estate investment is highly related to available market information and real estate market transparency. Jones Lang LaSalle (2004) argued that foreign real estate investors are not keen to invest in countries where domestic investors have easier access to information and therefore a competitive advantage, since the costs and risks of property transactions are high.

Similarly, Dhar and Goetzmann (2006) documented that more complete information about the long-term performance of real estate asset class can help resolve uncertainty and affect institutional investors' demand for different types of properties. He et al. (2009) provided evidences that foreign investors would favor those China's provinces with a more transparent real estate markets. More specifically, they argued that provinces that transfer their land use rights through a more open and transparent way would be attractive to foreign real estate investors. In his study on transparency and real estate investment, Triantafyllopoulos (2006) argued where there is no security of legal title and enforceability of property rights, domestic and international investors are not always willing to invest. 
Triantafyllopoulos further discussed that lack of information regarding real assets may cause a country to be ignored by real estate investors when they draw up their international investment strategies. Triantafyllopoulos also noted that when corruption dominates in property markets, the private marginal product of capital invested decrease because of the bribes that have to be paid, lowering the investment rate. As a result, participation of (domestic and foreign) investors in property market would decrease. Falkenbach (2009) found that one of the important criteria for market selection in international real estate investment is availability of market information and performance benchmarks (transparency). With regard to general FDI, Drabek and Payne (2002) also concluded that a nation that takes steps to increase the degree of transparency in its policies and institutions could expect significant increases in the level of foreign investment.

Property prices: Another hypothesis to be tested is the relationship between property prices in host countries and FREI. The rationale for selecting property prices as an independent variable is that real estate can be considered as financial assets, whose price changes would affect the quantity and direction of financial movements across borders (Rodri'guez and Bustillo, 2010).

Anumber of researchers found that heightening property prices in the host countries encourages foreign investment in real estate sectors of those countries (He et al., 2009; Zhu et al., 2006). For example, in their financial model for FREI in Spain, Rodri'guez and Bustillo (2010) found that there is a long-run and positive relationship between expectations of increasing prices for real estate assets and FREI in Spain. In particular, they argued that Spain is attractive for real estate investment because the future return of the present investment is expected to be high. Similarly, as mentioned earlier, He et al. (2009) showed that the heightening housing prices significantly stimulate the inflow of FDI in China's real estate industry.

In other words, He et al. (2009) argued that foreign investors in real estate lean towards those (China) provinces with higher average housing prices. Jones Lang LaSalle (2009) discussed that potential for capital growth is one of the main criteria for long-term investors in MENA countries' real estate sector. In his study, Bagchi-Sen (1995) also found that the value of property is one of major determinants of FDI in real estate sector in the USA. On the other hand, it can be argued that an increase in property prices have opposite effect on FREI. For example, in their demand model for real estate in a foreign country, Rodri'guez and Bustillo (2010) showed that there is a long-run and negative relationship between property prices and FREI in Spain. In other words, they argued that demand for housing services abroad is (negatively) influenced by their prices, consistent with demand theory.

Financing Cost: One of the possible determinants of FREI is the financing system in the host countries. It is because foreign investors in service sectors (including real estate) rely on the host country's financial systems to raise the capital that is required for their investment (Ramasamy and Yeung, 2010). Therefore, a high interest rate could negatively influence the extent of FDI inflow because a large amount of funds could be raised by foreign investors 
from the financial system of host countries. This argument is consistent with a number of previous studies.

He et al. (2009) found that foreign investors in China's real estate industry avoid provinces with high financing cost (or lower value for loan). This means that foreign investors favor provinces in which foreign investors are easy to borrow money from commercial banks. In their study on determinants of FREI in Spain, Rodrı'guez and Bustillo (2010) also found that FREI is negatively related to the long-term interest rate. With regard to general FDI, Zhao (2003) found that the relatively high costs of capital borrowing in China inhibited the flow of FDI.

The expenses associated with the nonperforming loans that results can create the appearance, if not the reality, of low cost efficiency. The authors refer to this as the "bad luck" hypothesis. The second empirical link between problem loans and productive efficiency appears in studies that use supervisory examination data. A relationship between asset quality and cost is consistent with the failed bank data, and suggests that the negative relationship between problem loans and cost efficiency holds for the population of banks as a whole as well as for failing banks. Third, some recent studies of bank efficiency have directly included measures of nonperforming loans in cost or production relationships.

Whether this procedure improves or hinders the estimation of cost efficiency depends upon the underlying reason for the relationship between costs and nonperforming loans. Thus, important policy and research issues rest on identifying the underlying relationship between problem loans and measured cost efficiency: The primary cause of problem loans and bank failures determining the most important supervisory focus for promoting safety and soundness at banks deciding how to estimate the cost efficiency of financial institutions. The authors test four hypotheses bad luck, bad management, skimping, and moral hazard using Granger-causality analysis.

The skimping hypothesis posits that banks might achieve low costs by under-spending on loan underwriting and monitoring in the short run, and after time passes this slack results in increases in problem loans. The authors test the moral hazard hypothesis by testing whether equity capital negatively Granger-causes nonperforming loans. The authors results suggest that the inter-temporal relationships between loan quality and cost efficiency run in both directions. http://ideas.repec.org/p/wop/pennin/96-01.html

Acquisition of real estate through bank loans: For the next several years, the commercial real estate mortgage market faces record levels of maturities. As shown in Figure 1, the annual amount of commercial mortgage loan maturities has risen steadily during the last decade from $\$ 50$ to $\$ 100$ billion in 2000 through 2003 to $\$ 200$ to $\$ 250$ billion in 2008 and 2009. Maturities are estimated to exceed $\$ 250$ billion per year from 2010 through 2015 and are not forecast to decline below $\$ 200$ billion per year until 2018. The level and extent of commercial mortgage maturities far exceed the level of maturities during the last major real estate downturn of the early 1990's. The continued economic recession combined with declines in rental rates, declines in occupancy levels, other deteriorating property fundamentals and increases in capitalization rates have caused declining property values. 


\section{Macrothink}

In the context of record levels of outstanding commercial mortgage debt, these factors place considerable stress on the ability of borrowers to service debt and to refinance scheduled maturities. While some loans might be refinanced or extended, many of these maturing loans will eventually result in other resolution strategies including workouts/restructurings, bankruptcies, discounted payoffs, or foreclosures. Distressed loans can be defined as loans that will follow one or more of these resolution paths. When pools of loans are involved, buyers and sellers use similar information to configure pools, determine specific assets on which to conduct diligence and develop pricing on either individual loans or on like kind loans using statistical sampling techniques and models. This article focuses on the acquisition of distressed notes and mortgages on real estate at the individual loan level and discusses the manner in which various post acquisition loan resolution strategies effect the due diligence and pricing in those acquisitions. For the purposes of this article, distressed commercial real estate debt is broadly defined to include both loans secured directly by mortgages on real property and loans secured by LLC, partnership or stock interest in entities whose assets consist primarily or exclusively of real property. Interests in collateralized mortgage backed securities, collateralized debt obligations, and similar structures are not covered in this article. http://scholarship.sha.cornell.edu/cgi/viewcontent.cgi?article $=1041 \&$ context $=$ crer

\section{Conceptual Framework}

\section{Hypotheses}

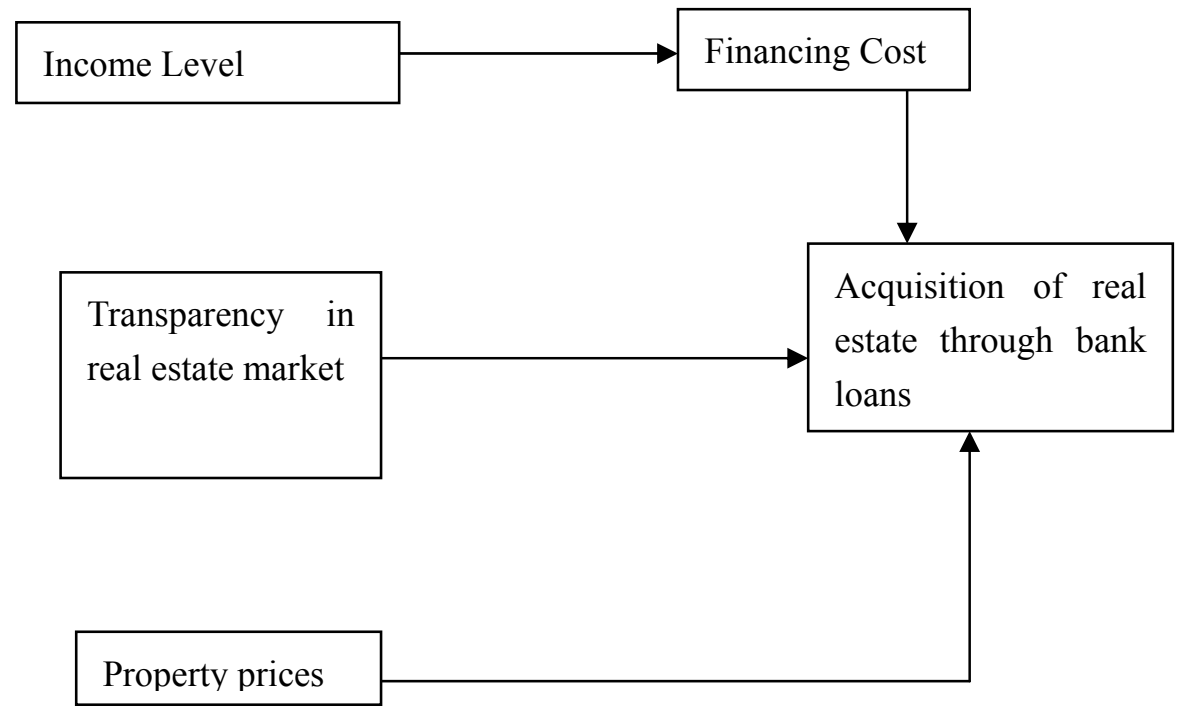

$\mathbf{H}_{\mathbf{0 1}}$ : There is no positive relationship between income level and acquisition of real estate through bank loans.

$\mathbf{H}_{\mathbf{a} 1}$ : There is a positive relationship between income level and acquisition of real estate through bank loans.

$\mathbf{H}_{\mathbf{0 2}}$ : There is no negative relationship between financing costs and acquisition of real estate through bank loans.. 
$\mathbf{H}_{\mathbf{a} 2}$ : There is a negative relationship between financing costs and acquisition of real estate through bank loans.

$\mathbf{H}_{\mathbf{0} 3}$ : Higher level of transparency in real estate market would not attract greater amount of acquisition of real estate through bank loans.

$\mathbf{H}_{\mathbf{a} 3}$ : Higher level of transparency in real estate market would attract greater amount of acquisition of real estate through bank loans.

$\mathbf{H}_{\mathbf{0 4}}$ : There is no relationship between property prices and acquisition of real estate through bank loans.

$\mathbf{H}_{\mathbf{a} 4}$ : There is a relationship between property prices and acquisition of real estate through bank loans.

$\mathbf{H}_{\mathbf{0 5}}$ : There is no relationship between the availability of bank loans and acquisition of real estate in Bangladesh.

$\mathbf{H}_{\mathbf{a} 5}$ : There is a relationship between the availability of bank loans and acquisition of real estate in Bangladesh.

\section{The Research Design-Methods and Procedures}

Research design is crucial as it acts as a blueprint for the collection, measurement and analysis of data. In this study, we selected formal research design. Because this study required structured and précised way to show the relationship among different variables and to test hypotheses.

Under the method of data collection, we selected communication study. Because we needed to communicate with different customers through questionnaire to understand their income level, financing cost, product pricing etc. which have significant impact on their acquisition of real estate investment through bank loans.

Our study was an experimental study. Because our study was required to gather information selective samples.

Our study was causal explanatory as we tried to explain the relationship among different variables such as we tried to discover whether bank loans can affect customers'financing decision.

Our study reflected a snapshot of one point in time. We studied on 100 customers as samples for and they did not need to be studied again for the same study.

We focused on statistical study and descriptive analysis. Our study was designed for testing the hypotheses quantitatively which required a good number of samples which reflected the population.

Our research occurred in actual environmental conditions. This option was chosen because we had to receive information from our sample on field and relationships in variables of our study were required to represent via mathematical models. 
Participants 'were aware of our presence and knew the reason of being selected as sample. We tried to find out their natural behavior as much as we could via questionnaire.

\section{Sampling}

\subsection{Sample unit}

Sample unit of research was based on customers who acquired real estate through the use of loans of banks or other financial institutions. In order to gather information, participants had been asked to fill up questionnaires. The population for the current research was the customers who use loans to acquire various real estate products in Bangladesh. In particular, the study revealed that the sample consisted of equal number of males than females and mostly people in the work force.

\subsection{Sample Size}

Sample size relates to how many people to pick for the study. We picked both male and female of different ages, educational back ground and occupation. The sample size for our study was 50.

\subsection{Sample Procedure}

This study utilized probability sampling technique that involved selecting participants randomly for questionnaires. Two facts were considered to select the participants for the questionnaires. Firstly, the sample members bought their real estate products from renowned companies were transparency of information was high and prices of the property was accurately determined according to the market rates. Secondly, these customers used or are using various loan product available from various financial institutions. In our case these customers information were mainly acquired from those groups who had taken a home loan from Standard Bank Limited.

\section{Instruments of Research}

The key variables in this study were measured by a self-report questionnaire. A self-report is any method which involves asking a participant about their feelings, attitudes, and beliefs and so on. The first part of the instrument included demographic characteristics of gender, age, income, occupation and educational background. The rest of the questionnaire assessed the five variables in the research hypotheses. There were 17 questions excluding demographic questions in the questionnaire.

Every variable has different questions for each and our questionnaire introduces five points likert scale to our participants. We had collected the information about online marketing from different participants from different areas and also collected participant's photos during the survey.

Our likert scale has five points. The points are First one is strongly disagree, Second one is disagree, Third one is neutral, forth one is agree and lastly fifth one is strongly agree. Our participants easily understand our rating scale and successfully completed the survey. 
Income Level and Financing Cost: By this variable we came to know that how online marketers 'recommendation affects the customers buying intention and how customers are inspired by the recommendation. In this section I have five questions in our questionnaire.

Transparency in Real Estate Market: This variable has three questions about how the customers believe the information which online marketers' are providing to them. In this section I have five questions in our questionnaire.

Property Prices: Every participant gave the good response on this because everyone likes to do online shopping now a day and this variable has two questions and by these two questions we can easily come to know that the participants attitude toward the online marketing.

Acquisition of Real Estate Through Bank Loans: Four questions for online brand image reflects the participants awareness how they are choosing the branded products and the company.

\section{Data collection}

Data collection was carried out in two ways: primary data and secondary data. In this research, we used both of the methods.

\section{Data Analysis}

\subsection{Descriptive Analysis:}

Descriptive analysis includes numbers that summarize the data with the purpose of describing what occurred in the sample. Our study involved 50 random samples.

Frequency distributions were which have been given under Table no. 1'. In my research, there were 33 male which was $66 \%$ of total sample under survey and the other 17 were female which consisted of 34\%. Fourteen participants were between 51-60 years of age that was $28 \%$. I had 3 participants above 60 years and who constituted $6 \%$. Thirteen participants in below 30 year and the percentage was 26\%. Twelve participants in 41-50 years and Eight participants in 30-40 years and they constituted $40 \%$.

All of my participants were service holder. From 50 participants I had 25 business men and their percentage was 50\%. I had 16 service holders (Private Sector) and 9 service holder (Public Sector) who constituted 32\% and 18\% from total questionnaire.

In my questionnaire I had found 17 participants who finished their Post Graduation and 10 participants were completed Under Graduation and combining both degrees I found 54\% of our participants are well educated. Thirteen participants completed Diploma and Ten participants only completed their HSC which I categorized by other and both group constituted $46 \%$ of total questionnaire.

I had five categories for income and 17 participants were in between Tk. 100000-Tk. 300000 and they constituted $34 \%$ which was majority of our questionnaire. I had 12 participants whose income level was below Tk. 100000 and the percentage was $24 \%$. 7 participants were 


\section{Macrothink}

Asian Journal of Finance \& Accounting ISSN 1946-052X 2014, Vol. 6, No. 2

from Tk. 300001-Tk. 500000 and they constituted 14\%. I had also 3 participants from Above Tk. 700000 and 11 participants from Tk. 500001-Tk. 700000 both constituted $28 \%$.

Table 1. Frequency Distribution

Statistics

\begin{tabular}{|c|c|c|c|c|c|c|}
\hline & & Gender & Age & $\begin{array}{l}\text { Annual } \\
\text { Income }\end{array}$ & Occupation & Education \\
\hline \multirow[t]{2}{*}{$\mathrm{N}$} & Valid & 50 & 50 & 50 & 50 & 50 \\
\hline & Missing & 0 & 0 & 0 & 0 & 0 \\
\hline
\end{tabular}

Gender

\begin{tabular}{|c|c|c|c|c|c|}
\hline & & Frequency & Percent & Valid Percent & $\begin{array}{l}\text { Cumulative } \\
\text { Percent }\end{array}$ \\
\hline \multirow[t]{3}{*}{ Valid } & Male & 33 & 66.0 & 66.0 & 66.0 \\
\hline & Female & 17 & 34.0 & 34.0 & 100.0 \\
\hline & Total & 50 & 100.0 & 100.0 & \\
\hline
\end{tabular}

Age

\begin{tabular}{|cl|l|l|l|l|}
\hline & & & & $\begin{array}{l}\text { Cumulative } \\
\text { Percent }\end{array}$ \\
\hline Valid & Below 30 & 13 & 26.0 & 26.0 & 26.0 \\
& $30-40$ & 8 & 16.0 & 16.0 & 42.0 \\
$41-50$ & 12 & 24.0 & 24.0 & 66.0 \\
$51-60$ & 14 & 28.0 & 28.0 & 94.0 \\
Above 60 & 3 & 6.0 & 6.0 & 100.0 \\
Total & 50 & 100.0 & 100.0 & \\
\hline
\end{tabular}


Annual Income

\begin{tabular}{|c|c|c|c|c|c|}
\hline & & Frequency & Percent & Valid Percent & $\begin{array}{l}\text { Cumulative } \\
\text { Percent }\end{array}$ \\
\hline \multirow[t]{6}{*}{ Valid } & Below Tk. 100000 & 12 & 24.0 & 24.0 & 24.0 \\
\hline & $\begin{array}{ll}\text { Tk. } & 100000-T k \\
300000 & \end{array}$ & 17 & 34.0 & 34.0 & 58.0 \\
\hline & $\begin{array}{ll}\text { Tk. } & 300001-T k \\
500000\end{array}$ & 7 & 14.0 & 14.0 & 72.0 \\
\hline & $\begin{array}{ll}\text { Tk. } & 500001-\mathrm{Tk} . \\
700000 & \end{array}$ & 11 & 22.0 & 22.0 & 94.0 \\
\hline & Above Tk. 700000 & 3 & 6.0 & 6.0 & 100.0 \\
\hline & Total & 50 & 100.0 & 100.0 & \\
\hline
\end{tabular}

Occupation

\begin{tabular}{|ll|l|l|l|l|}
\hline & Frequency & Percent & Valid Percent & $\begin{array}{l}\text { Cumulative } \\
\text { Percent }\end{array}$ \\
\hline Valid & Service In Public Sector & 9 & 18.0 & 18.0 & 18.0 \\
& $\begin{array}{l}\text { Service In Private } \\
\text { Sector }\end{array}$ & 16 & 32.0 & 32.0 & 50.0 \\
$\begin{array}{l}\text { Self } \\
\text { (Business) }\end{array}$ & Employed & 25 & 50.0 & 50.0 & 100.0 \\
Total & 50 & 100.0 & 100.0 & \\
\hline
\end{tabular}

Education

\begin{tabular}{|c|c|c|c|c|c|}
\hline & & Frequency & Percent & Valid Percent & $\begin{array}{l}\text { Cumulative } \\
\text { Percent }\end{array}$ \\
\hline \multirow[t]{5}{*}{ Valid } & Post Graduate & 17 & 34.0 & 34.0 & 34.0 \\
\hline & Under Graduate & 10 & 20.0 & 20.0 & 54.0 \\
\hline & Diploma & 13 & 26.0 & 26.0 & 80.0 \\
\hline & Others & 10 & 20.0 & 20.0 & 100.0 \\
\hline & Total & 50 & 100.0 & 100.0 & \\
\hline
\end{tabular}




\section{Macrothink}

Asian Journal of Finance \& Accounting ISSN 1946-052X 2014, Vol. 6, No. 2

Cross tabulation was also done which has been shown under Table 2

Table 2. Cross Tabulation Calculation

Case Processing Summary

\begin{tabular}{|c|c|c|c|c|c|c|}
\hline \multirow{2}{*}{} & \multicolumn{6}{|c|}{ Cases } \\
\cline { 2 - 8 } & \multicolumn{2}{|c|}{ Valid } & \multicolumn{2}{c|}{ Missing } & \multicolumn{2}{c|}{ Total } \\
\cline { 2 - 8 } & $\mathrm{N}$ & Percent & $\mathrm{N}$ & Percent & $\mathrm{N}$ & Percent \\
\hline Gender * Age & 50 & $100.0 \%$ & 0 & $.0 \%$ & 50 & $100.0 \%$ \\
\hline
\end{tabular}

Gender * Age Cross tabulation

Count

\begin{tabular}{|c|c|c|c|c|c|c|c|}
\hline & \multicolumn{5}{|c|}{ Age } & \multirow[b]{2}{*}{ Total } \\
\hline & & Below 30 & $30-40$ & $41-50$ & $51-60$ & Above 60 & \\
\hline \multirow[t]{3}{*}{ Gender } & Male & 8 & 3 & 10 & 10 & 2 & 33 \\
\hline & Female & 5 & 5 & 2 & 4 & 1 & 17 \\
\hline & & 13 & 8 & 12 & 14 & 3 & 50 \\
\hline
\end{tabular}

Case Processing Summary

\begin{tabular}{|c|c|c|c|c|c|c|}
\hline \multirow{2}{*}{} & \multicolumn{6}{|c|}{ Cases } \\
\cline { 2 - 7 } & \multicolumn{2}{|c|}{ Valid } & \multicolumn{2}{c|}{ Missing } & \multicolumn{2}{c|}{ Total } \\
\cline { 2 - 7 } & $\mathrm{N}$ & Percent & $\mathrm{N}$ & Percent & $\mathrm{N}$ & Percent \\
\hline Gender * Annual & 50 & $100.0 \%$ & 0 & $.0 \%$ & 50 & $100.0 \%$ \\
Income & & & & & & \\
Gender * Occupation & 50 & $100.0 \%$ & 0 & $.0 \%$ & 50 & $100.0 \%$ \\
Gender * Education & 50 & $100.0 \%$ & 0 & $.0 \%$ & 50 & $100.0 \%$ \\
\hline
\end{tabular}

Gender * Annual Income Cross tabulation

Count

\begin{tabular}{|c|c|c|c|c|c|c|}
\hline & \multicolumn{5}{|c|}{ Annual Income } & \multirow[b]{2}{*}{ Total } \\
\hline & $\begin{array}{c}\text { Below Tk. } \\
100000\end{array}$ & $\begin{array}{c}\text { Tk. } \\
\text { 100000-Tk. } \\
300000\end{array}$ & $\begin{array}{c}\text { Tk. } \\
\text { 300001-Tk. } \\
500000\end{array}$ & $\begin{array}{c}\text { Tk. } \\
500001-\mathrm{Tk} . \\
700000\end{array}$ & $\begin{array}{c}\text { Above Tk. } \\
700000\end{array}$ & \\
\hline Gender Male & 7 & 12 & 4 & 8 & 2 & 33 \\
\hline Female & 5 & 5 & 3 & 3 & 1 & 17 \\
\hline Total & 12 & 17 & 7 & 11 & 3 & 50 \\
\hline
\end{tabular}


Gender * Occupation Cross tabulation

Count

\begin{tabular}{|c|c|c|c|c|c|}
\hline & \multicolumn{3}{|c|}{ Occupation } & \multirow[b]{2}{*}{ Total } \\
\hline & & $\begin{array}{c}\text { Service In Public } \\
\text { Sector }\end{array}$ & $\begin{array}{c}\text { Service In Private } \\
\text { Sector }\end{array}$ & $\begin{array}{l}\text { Self Employed } \\
\text { (Business) }\end{array}$ & \\
\hline \multirow[t]{3}{*}{ Gender } & Male & 6 & 10 & 17 & 33 \\
\hline & Female & 3 & 6 & 8 & 17 \\
\hline & & 9 & 16 & 25 & 50 \\
\hline
\end{tabular}

Gender * Education Cross tabulation

Count

\begin{tabular}{|c|c|c|c|c|c|c|}
\hline & \multicolumn{4}{|c|}{ Education } & \multirow[b]{2}{*}{ Total } \\
\hline & & Post Graduate & Under Graduate & Diploma & Others & \\
\hline \multirow[t]{3}{*}{ Gender } & Male & 9 & 8 & 10 & 6 & 33 \\
\hline & Female & 8 & 2 & 3 & 4 & 17 \\
\hline & & 17 & 10 & 13 & 10 & 50 \\
\hline
\end{tabular}

Case Processing Summary

\begin{tabular}{|c|c|c|c|c|c|c|}
\hline \multirow{2}{*}{} & \multicolumn{4}{|c|}{ Cases } \\
\cline { 2 - 7 } & \multicolumn{2}{|c|}{ Valid } & \multicolumn{2}{c|}{ Missing } & \multicolumn{2}{c|}{ Total } \\
\cline { 2 - 7 } & $\mathrm{N}$ & Percent & $\mathrm{N}$ & Percent & $\mathrm{N}$ & Percent \\
\hline Age * Annual Income & 50 & $100.0 \%$ & 0 & $.0 \%$ & 50 & $100.0 \%$ \\
Age * Occupation & 50 & $100.0 \%$ & 0 & $.0 \%$ & 50 & $100.0 \%$ \\
Age * Education & 50 & $100.0 \%$ & 0 & $.0 \%$ & 50 & $100.0 \%$ \\
\hline
\end{tabular}


Age * Annual Income Cross tabulation

\begin{tabular}{|c|c|c|c|c|c|c|c|}
\hline \multicolumn{8}{|c|}{ Count } \\
\hline & & \multicolumn{5}{|c|}{ Annual Income } & \multirow[b]{2}{*}{ Total } \\
\hline & & $\begin{array}{c}\text { Below Tk. } \\
100000\end{array}$ & $\begin{array}{c}\text { Tk. } \\
\text { 100000-Tk. } \\
300000\end{array}$ & $\begin{array}{c}\text { Tk. } \\
\text { 300001-Tk. } \\
500000\end{array}$ & $\begin{array}{c}\text { Tk. } \\
500001-\mathrm{Tk} . \\
700000\end{array}$ & $\begin{array}{c}\text { Above Tk. } \\
700000\end{array}$ & \\
\hline \multirow[t]{6}{*}{ Age } & $\begin{array}{c}\text { Below } \\
30\end{array}$ & 9 & 4 & 0 & 0 & 0 & 13 \\
\hline & $30-40$ & 0 & 3 & 2 & 3 & 0 & 8 \\
\hline & $41-50$ & 2 & 4 & 3 & 2 & 1 & 12 \\
\hline & $51-60$ & 0 & 6 & 2 & 4 & 2 & 14 \\
\hline & $\begin{array}{c}\text { Above } \\
60\end{array}$ & 1 & 0 & 0 & 2 & 0 & 3 \\
\hline & Total & 12 & 17 & 7 & 11 & 3 & 50 \\
\hline
\end{tabular}

Age * Occupation Cross tabulation

Count

\begin{tabular}{|c|c|c|c|c|c|}
\hline & \multicolumn{3}{|c|}{ Occupation } & \multirow[b]{2}{*}{ Total } \\
\hline & & $\begin{array}{c}\text { Service In } \\
\text { Public Sector }\end{array}$ & $\begin{array}{c}\text { Service In } \\
\text { Private Sector }\end{array}$ & $\begin{array}{c}\text { Self Employed } \\
\text { (Business) }\end{array}$ & \\
\hline \multirow[t]{6}{*}{ Age } & Below 30 & 1 & 9 & 3 & 13 \\
\hline & $30-40$ & 1 & 1 & 6 & 8 \\
\hline & $41-50$ & 4 & 2 & 6 & 12 \\
\hline & $51-60$ & 3 & 2 & 9 & 14 \\
\hline & Above 60 & 0 & 2 & 1 & 3 \\
\hline & Total & 9 & 16 & 25 & 50 \\
\hline
\end{tabular}


Age * Education Cross tabulation

Count

\begin{tabular}{|c|c|c|c|c|c|}
\hline & \multicolumn{4}{|c|}{ Education } & \multirow{2}{*}{} \\
\cline { 2 - 5 } & Post Graduate & $\begin{array}{c}\text { Under } \\
\text { Graduate }\end{array}$ & Diploma & Others & Total \\
\hline Age Below 30 & 2 & 5 & 5 & 1 & 13 \\
$30-40$ & 5 & 0 & 1 & 2 & 8 \\
$41-50$ & 8 & 2 & 1 & 1 & 12 \\
$51-60$ & 1 & 3 & 5 & 5 & 14 \\
Above 60 & 1 & 0 & 1 & 1 & 3 \\
Total & 17 & 10 & 13 & 10 & 50 \\
\hline
\end{tabular}

\subsection{Reliability Analysis}

Internal consistency reliability is the accuracy or precision of a measuring instrument, which is the extent of unidimensionality, that is, the detailed items (questions) measure the same thing. The internal consistency reliability was assessed by calculating Cronbach's a value. A commonly accepted rule of thumb for describing internal consistency using Cronbach's alpha (http://en.wikipedia.org/wiki/Cronbach's_alpha\#cite_note-Cortina-8) is as follows-

$$
\begin{array}{ll}
\checkmark & \alpha \geq 0.9 \text { Excellent } \\
\checkmark & 0.7 \leq \alpha<0.9 \text { Good } \\
\checkmark & 0.6 \leq \alpha<0.7 \text { Acceptable } \\
\checkmark & 0.5 \leq \alpha<0.6 \text { Poor } \\
\checkmark & \alpha<0.5 \text { Unacceptable }
\end{array}
$$

In my research, I had calculated Cronbach's alpha for each variable under each sample group which has been shown under Table $3^{6}$.

Table 3. Reliability Calculation

Income Level:

Case Processing Summary

\begin{tabular}{|rl|r|r|}
\hline & & $\mathrm{N}$ & \multicolumn{1}{c|}{$\%$} \\
\hline Cases & Valid & 50 & 100.0 \\
& Excluded $^{\mathrm{a}}$ & 0 & .0 \\
& Total & 50 & 100.0 \\
\hline
\end{tabular}


Case Processing Summary

\begin{tabular}{|ll|r|r|}
\hline & & $\mathrm{N}$ & \multicolumn{1}{c|}{$\%$} \\
\hline Cases & Valid & 50 & 100.0 \\
& Excluded $^{\mathrm{a}}$ & 0 & .0 \\
& Total & 50 & 100.0 \\
\hline
\end{tabular}

a. Listwise deletion based on all variables in the procedure.

Financing Cost:

Case Processing Summary

\begin{tabular}{|ll|r|r|}
\hline & & $\mathrm{N}$ & $\%$ \\
\hline Cases & Valid & 50 & 100.0 \\
& Excluded $^{\mathrm{a}}$ & 0 & .0 \\
& Total & 50 & 100.0 \\
\hline
\end{tabular}

Transparency in Real Estate Market:

Case Processing Summary

\begin{tabular}{|ll|r|r|}
\hline & & N & $\%$ \\
\hline Cases & Valid & 50 & 100.0 \\
& Excluded $^{\mathrm{a}}$ & 0 & .0 \\
& Total & 50 & 100.0 \\
\hline
\end{tabular}

a. Listwise deletion based on all variables in the procedure.
Reliability Statistics

\begin{tabular}{|r|r|}
\hline $\begin{array}{c}\text { Cronbach's } \\
\text { Alpha }\end{array}$ & N of Items \\
\hline .609 & 2 \\
\hline
\end{tabular}

Reliability Statistics

\begin{tabular}{|r|r|}
\hline $\begin{array}{c}\text { Cronbach's } \\
\text { Alpha }\end{array}$ & N of Items \\
\hline .755 & 5 \\
\hline
\end{tabular}


Property Prices:

Case Processing Summary

\begin{tabular}{|rl|r|r|}
\hline & & $\mathrm{N}$ & $\%$ \\
\hline Cases & Valid & 50 & 100.0 \\
& Excluded $^{\mathrm{a}}$ & 0 & .0 \\
& Total & 50 & 100.0 \\
\hline
\end{tabular}

a. Listwise deletion based on all

Reliability Statistics

\begin{tabular}{|r|r|}
\hline $\begin{array}{c}\text { Cronbach's } \\
\text { Alpha }^{\mathrm{a}}\end{array}$ & N of Items \\
\hline .798 & 4 \\
\hline
\end{tabular}

variables in the procedure.

Acquisition of Real Estate through Bank Loans:

Case Processing Summary

\begin{tabular}{|rl|r|r|}
\hline & & $\mathrm{N}$ & \multicolumn{1}{c|}{$\%$} \\
\hline Cases & Valid & 50 & 100.0 \\
& Excluded $^{\mathrm{a}}$ & 0 & .0 \\
& Total & 50 & 100.0 \\
\hline
\end{tabular}

Reliability Statistics

\begin{tabular}{|r|r|}
\hline $\begin{array}{l}\text { Cronbach's } \\
\text { Alpha }\end{array}$ & N of Items \\
\hline .659 & 3 \\
\hline
\end{tabular}

a. Listwise deletion based on all variables in the procedure.

For variable Income Level Cronbach's alpha is .616 which indicates acceptable and good internal consistency respectively for this variable.

In case of variable Financing Cost, this result is .609 for which also indicates acceptable and good internal consistency for this variable.

For Variable Transparency in Real Estate Market the result is .755 which indicates good internal consistency for this variable.

The Cronbach's alpha for the variable Property Pricing is .798 which reflects good internal consistency for this variable.

In case of variable Acquisition of Real Estate through Bank Loans, this result is .659 this indicate acceptable internal consistency for this variable.

\section{Limitations}

It was impossible for us to prepare a report without limitations. There are some limitations in this research which were-

- Data collection was restricted within Dhaka city only, which might fail to represent the factual scenario of the relationship between measured variables.

- Sample size was 50 which were very small to represent the proposed scenario. 
- I had to face time constraints and money constrains that led to get narrower outcomes.

\section{Significance of Study}

Bangladesh is a small but one of the most densely populated countries in the world with quite a small and poor economy. Majority of its population fall in the low income bracket and therefore basic needs fulfillment is the main concern for them. One of the five basic needs is shelter and state is supposed to ensure that. But state can't do that due to resources scarcity and this is the point in which most experts stick on for the development of the real estate sector in Bangladesh. The sector is dominated by the private investors, though the government is present in the market through some housing projects. These private investors are widely treated as profit concerns, but they are working hard to meet the rising housing demand in the country too.

Bank loans have an increasing role for corporate activities. In most countries, bank loans are the main source of financing for small and medium-sized enterprises. Even though the role of banks decreased in the last years, banks take advantage of a privileged position which allows them to provide liquidity cheaply than other intermediaries. The activity of bank lending is often influenced by the adverse selection due to the fact that corporate clients are often reluctant, in providing the complete and real information about them. As a result the information asymmetry may have a negative impact both on banks and companies. The most important effects of the financial and economic crisis on the companies are the drastic drop in demand for goods and services and a tightening in credit terms, which are severely affecting their cash flows. Also, companies face financing constraints which often amplify the effects of crisis.

Land scarcity and the lack of social security are the two major reasons people think lie behind the development of the real estate sector in Bangladesh. There are other important factors too for example price of houses, rapid growth in population, rapid urbanization, and complexities in buying lands to build houses etc. Though there are varied opinions for what the sector has been developed in Bangladesh, almost all the respondents and real estate experts think that the development of the real estate sector was obvious in Bangladesh mainly to meet the rising demands for houses across the country. Public sector's failure to ensure the housing for the total population enhanced the development.

Majority of the population is not satisfied about the current practice of the sector. They think companies are mainly profits concern and don't care about the quality of their services.

\section{References}

Arnold, J., Javorcik, B.S., \& Mattoo, A. (2006). The productivity effects of services liberalization evidence from the Czech Republic. World Bank's Research Program, World Bank, Washington, DC, mimeo.

Bagchi-Sen, S. (1995). FDI in US producer services: a temporal analysis of foreign directinvestment in the finance, insurance and real estate sectors. Regional Studies, 29(2),159-170. http://dx.doi.org/10.1080/00343409512331348873 
Baltagi, B.H. (2005), Econometric Analysis of Panel Data, 3rd ed., Willey, Chichester.

Bardhan, A., \& Kroll, C. A. (2007). Globalization and the real estate industry: issues,implications, opportunities. paper prepared for the Sloan Industry Studies AnnualConference, Cambridge, April.

Basu, B., \& Yao, J. (2009). Foreign direct investment and skill formation in China.International Economic Journal, 23(2), 163-179. http://dx.doi.org/10.1080/10168730902901106

Brown, G.R., \& Matysiak, G.A. (2000), Real Estate Investment: A Capital Market Approach. Financial Times/Prentice-Hall, Singapore.

Busse, M., \& Hefeker, C. (2007). Political risk, institutions and foreign direct investment.European Journal of Political Economy, 23(2), 397-415. http://dx.doi.org/10.1016/j.ejpoleco.2006.02.003

Chen, C.H. (1996). Regional determinants of foreign direct investment in mainland $\begin{array}{llll}\text { China.Journal of Economic } & \text { Studies, } & 23(2), & \text { 18-30. }\end{array}$ http://dx.doi.org/10.1108/01443589610109649

Chin, W., Dent, P., \& Roberts, C. (2006). An exploratory analysis of barriers to investment andmarket maturity in Southeast Asian cities. Journal of Real Estate Portfolio Management, 12(1), 49-58.

Chuang, C.C., \& Wang, Y.H. (2009). Developed stock market reaction to political change:a panel data analysis. Quality and Quantity, 43(6), 941-949. http://dx.doi.org/10.1007/s11135-009-9230-2

Colman, \& Alesina et al. (1990). Repeated interactions being conducive of social capital and trust, heterogeneous societies are thus characterized by fewer contacts and, in consequence, by lower levels of cooperation and trust see the seminal work by http://scholarship.sha.cornell.edu/cgi/viewcontent.cgi?article=1041\&context=crer $\quad$ (July 6, 2014)

Cordero, J., \& Paus, E. (2008). Foreign investment and economic development in Costa Rica:the unrealized potential. Working Group on Development and Environment in the Americas, Discussion Paper No13, April.

Costas, \& Kahn. (2003). Informal social capital such as entertaining with friends and relatives http://scholarship.sha.cornell.edu/cgi/viewcontent.cgi?article=1041\&context=crer $\quad$ (July 6, 2014)

D'Arcy, E. (2009). The evolution of institutional arrangements to support theinternationalization of real estate involvements: some evidence from Europe. Journal ofEuropean Real Estate Research, 280-293. http://dx.doi.org/10.1108/17539260911000006 
Dhar, \& Goetzmann. (2006). documented that more complete information about the long-term performance of real estate asset class can help resolve uncertainty and affect institutional investors' demand for different types of properties http://scholarship.sha.cornell.edu/cgi/viewcontent.cgi?article=1041\&context=crer $\quad$ July 6, 2014)

http://ideas.repec.org/p/wop/pennin/96-01.html

Jones Lang LaSalle. (2008). It has been argued that more transparent real estate markets attract greater levels of foreign investors as they become more comfortable and better informed

Knack, \& Keefer. (1997). This creates an environment not favorable to the development of social capital http://scholarship.sha.cornell.edu/cgi/viewcontent.cgi?article=1041\&context=crer $\quad$ (July 6 , 2014)

Liao, \& Mei. (1999). empirically examined the relationship between institutional factors and real estate returns using data from developed and emerging market countries http://scholarship.sha.cornell.edu/cgi/viewcontent.cgi?article=1041\&context $=$ crer $\quad$ (July 6 , 2014)

Sirmans and Worzala. (2003). In their comprehensive summary, concluded that international real estate investment is highly related to available market information and real estate market transparency

http://scholarship.sha.cornell.edu/cgi/viewcontent.cgi?article=1041\&context=crer $\quad$ (July 6 , 2014)

Uslaner, \& Brown. (2005). argue that when income inequality is high, individuals from different socioeconomic groups will have the sensation that they are not sharing the same fate, and this will hamper trust http://scholarship.sha.cornell.edu/cgi/viewcontent.cgi?article=1041\&context=crer $\quad$ (July 6 , 2014)

Uslaner, \& Brown. (2005). Informal social capital such as entertaining with friends and relatives http://scholarship.sha.cornell.edu/cgi/viewcontent.cgi? article $=1041 \&$ context $=$ crer (July 6, 2014)

\section{Appendix}

Appendix 1. Survey Question

\section{Questionnaire}

Dear Respondent,

The questionnaire is aimed at understanding the use of bank loans to acquire real estate property in Bangladesh and the various factors that effects this acquisition process. Your response will be dealt 


\section{Macrothink}

Asian Journal of Finance \& Accounting ISSN 1946-052X 2014, Vol. 6, No. 2

with strict confidentiality and it will be used only for academic purpose. Thank you for spending your valuable time to fill this questionnaire.

1. Gender: Male

Female

2. Age: Below 30

$$
31-40
$$$$
41-50
$$$$
51-60
$$

Above 60

\section{Occupation:}

Service In Public Sector

Service In Private Sector

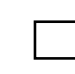

Self Employed (Business)
3. Annual Income: Below Tk. 100000

Tk. 100000-Tk. 300000

Tk. 300001-Tk.500000

Tk. 500001-Tk. 700000

Above Tk. 700000

5. Education: Post Graduate

$$
\text { Diploma }
$$

Others

\section{Under Graduate}
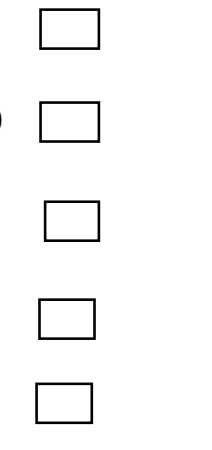

Level of agreement regarding the following statements:

$\begin{array}{ll}1=\text { Strongly Disagree } & 2=\text { Disagree } \\ 4=\text { Agree } & 5=\text { Strongly Agree }\end{array}$

Please mark $(\sqrt{ })$ the number which most closely responds to your thinking.

\section{$\underline{\text { Income Level and Financing Cost }}$}

1. Based on your current income level did you consider a real estate investment.

$\begin{array}{lllll}1 & 2 & 3 & 4 & 5\end{array}$

2. Do you plan to use your savings/inheritance as a source of funding for real estate investment.

$\begin{array}{lllll}1 & 2 & 3 & 4 & 5\end{array}$

3. Did you approach any financial institutions / banks for loan purposes for real estate acquisition.

$\begin{array}{llllll}1 & 2 & 3 & 4 & 5\end{array}$ 
4. Do you think the current financing cost of this loans provided by the financial institutions/banks are competitive.

\section{$\begin{array}{lllll}1 & 2 & 3 & 4 & 5\end{array}$}

5. Is your income sufficient to meet the interest payments of these loans (should you consider to take one) if you think of a recent / have carried out a recent investment in real estate.

$\begin{array}{lllll}1 & 2 & 3 & 4 & 5\end{array}$

\section{$\underline{\text { Transparency in Real Estate Market }}$}

6. Do you consider the current real estate market of Bangladesh a transparent one in terms of companies promising clients an estimating complacent timings of project.
$\begin{array}{lllll}1 & 2 & 3 & 4 & 5\end{array}$

7. Do you consider transparency in terms of pricing of raw materials an important factor.

$$
\begin{array}{lllll}
1 & 2 & 3 & 4 & 5
\end{array}
$$

8. Lack of transparency will lead to problems in relation to loan interest payment.

$$
\begin{array}{lllll}
1 & 2 & 3 & 4 & 5
\end{array}
$$

9. Does this transparency create an impact on your disposable income level if you have already used financing for real estate investment.

$\begin{array}{lllll}1 & 2 & 3 & 4 & 5\end{array}$

10. Do you think this transparency will impact your decision to invest in real estate in using financing options in future given your current income level.

$\begin{array}{lllll}1 & 2 & 3 & 4 & 5\end{array}$

\section{$\underline{\text { Property Prices }}$}

11. Do you think property price changes in Bangladesh follows a fixed trend.

$$
\begin{array}{lllll}
1 & 2 & 3 & 4 & 5
\end{array}
$$

12. Do you think financial institutions/banks in Bangladesh should provide a fixed interest rate irrespective of property price fluctuation.

$$
\begin{array}{lllll}
1 & 2 & 3 & 4 & 5
\end{array}
$$

13. Do you think property prices in Bangladesh is investment friendly given your current income level.

\section{$\begin{array}{lllll}1 & 2 & 3 & 4 & 5\end{array}$}

14. Do you think property prices in Bangladesh is investment friendly given the average interest rate on average amount of loan taken by an average investors.

$$
\begin{array}{lllll}
1 & 2 & 3 & 4 & 5
\end{array}
$$

\section{Acquisition of Real Estate Through Bank Loans}


15. Do you think that acquisition of real estate through bank loan is a common trend in Bangladesh.

$\begin{array}{lllll}1 & 2 & 3 & 4 & 5\end{array}$

16. Do you think banks in Bangladesh are promoting their investment loan products in an appreciable manner to prospective investors.

$\begin{array}{lllll}1 & 2 & 3 & 4 & 5\end{array}$

17. Do you think banks are providing a good loan protection/insurance for investors using financing for real estate investment.

$\begin{array}{lllll}1 & 2 & 3 & 4 & 5\end{array}$ 